Bird Conservation International (2021) 31:169-184. C The Author(s), 2020. Published by Cambridge University Press on behalf of BirdLife International. This is an Open Access article, distributed under the terms of the Creative Commons Attribution licence (http://creativecommons.org/licenses/by/4.o/), which permits unrestricted re-use, distribution, and reproduction in any medium, provided the original work is properly cited.

doi:10.1017/S0959270920000398

\title{
Modelling the potential non-breeding distribution of Spoon-billed Sandpiper Calidris pygmaea
}

\author{
TOM BRADFER-LAWRENCE ${ }^{1,2 *}$ (D), ALISON E. BERESFORD ${ }^{2}$, \\ GUY Q. A. ANDERSON ${ }^{3}$, PYAE PHYO AUNG ${ }^{4}$, QING CHANG ${ }^{5}$, \\ SAYAM U. CHOWDHURY ${ }^{6}$, NIGEL A. CLARK ${ }^{7}$, YURI N. GERASIMOV ${ }^{8}$, \\ RHYS E. GREEN ${ }^{9}$, GEOFF M. HILTON ${ }^{10}$, BAZ HUGHES ${ }^{10}$, ELENA G. LAPPO ${ }^{11}$, \\ JING LI ${ }^{12}$, EVGENY E. SYROECHKOVSKIY ${ }^{13}$, PAVEL S. TOMKOVICH ${ }^{14}$, \\ CHRISTOPH ZOCKLER ${ }^{15}$ and GRAEME M. BUCHANAN ${ }^{2}$
}

${ }^{1}$ School of Biological and Environmental Sciences, University of Stirling, Stirling, UK.

${ }^{2} R S P B$ Centre for Conservation Science, Royal Society for the Protection of Birds, 2 Lochside View, Edinburgh EH12 9DH, UK.

${ }^{3}$ RSPB Centre for Conservation Science, Royal Society for the Protection of Birds, The Lodge, Sandy, Bedfordshire, UK.

${ }^{4}$ Biodiversity and Nature Conservation Association, Yangon, Myanmar.

${ }^{5}$ College of Life Sciences, Nanjing Normal University, Nanjing 210023, China.

${ }^{6}$ Bangladesh Spoon-billed Sandpiper Conservation Project. 16/C Tallabag, Sobhanbag, Dhaka-1207, Bangladesh.

${ }^{7}$ British Trust for Ornithology, Thetford, UK.

${ }^{8}$ Kamchatka Branch of Pacific Institute of Geography, Far East Branch of Russian Academy of Sciences, Pr. Rybakov, 19a, Petropavlovsk-Kamchatsky, 683024, Russia.

${ }^{9}$ Department of Zoology, University of Cambridge, Downing Street, Cambridge, UK.

${ }^{10}$ Wildfowl and Wetlands Trust, Slimbridge, Gloucester, UK.

${ }^{11}$ Institute of Geography, Russian Academy of Sciences, Staromonetniy pereulok, 29, Moscow, 119017, Russia.

${ }^{12}$ Spoon-billed Sandpiper (Shanghai) Environmental Protection Technology Co., Ltd., Shanghai, 201100, China.

${ }^{13}$ BirdsRussia and All-Russian Research Institute for Environment Protection 36-th km MKAD, 1, build. 4, Moscow, 117628, Russia.

${ }^{14}$ Zoological Museum, Lomonosov Moscow State University, Bolshaya Nikitskatya St., 2, 125009 Moscow, Russia.

${ }^{15}$ ArcCona Consulting, Spoon-billed Sandpiper Task Force, Cambridge, UK.

*Author for correspondence; email: tom.bradfer-lawrence@stir.ac.uk

(Received 20 January 2020; revision accepted 23 June 2020)

\section{Summary}

The Spoon-billed Sandpiper Calidris pygmaea is a 'Critically Endangered' migratory shorebird. The species faces an array of threats in its non-breeding range, making conservation intervention essential. However, conservation efforts are reliant on identifying the species' key stopover and wintering sites. Using Maximum Entropy models, we predicted Spoon-billed Sandpiper distribution across the non-breeding range, using data from recent field surveys and satellite tracking. 
Model outputs suggest only a limited number of stopover sites are suitable for migrating birds, with sites in the Yellow Sea and on the Jiangsu coast in China highlighted as particularly important. All the previously known core wintering sites were identified by the model including the GangesBrahmaputra Delta, Nan Thar Island and the Gulf of Mottama. In addition, the model highlighted sites subsequently found to be occupied, and pinpointed potential new sites meriting investigation, notably on Borneo and Sulawesi, and in parts of India and the Philippines. A comparison between the areas identified as most likely to be occupied and protected areas showed that very few locations are covered by conservation designations. Known sites must be managed for conservation as a priority, and potential new sites should be surveyed as soon as is feasible to assess occupancy status. Site protection should take place in concert with conservation interventions including habitat management, discouraging hunting, and fostering alternative livelihoods.

Keywords: distribution modelling, flyway, migratory, shorebird

\section{Introduction}

The Spoon-billed Sandpiper Calidris pygmaea is a Critically Endangered calidrid found in Asia (BirdLife International 2017). The species breeds in north-east Siberia, migrates through the East Asian-Australasian flyway with stopover sites in the Yellow Sea, and is thought to winter principally in South China, Thailand, Myanmar, and Bangladesh (Chowdhury 2012, Lappo et al. 2012, Zöckler et al. 2016). The estimated global population of Spoon-billed Sandpiper fell from around 2 ,ooo pairs in the 1970 s to under 200 in 2014, with a rate of decline up to $26 \%$ per annum recorded during the 2000 (Flint and Kondratiev 1977, Tomkovich et al. 2002, Zöckler et al. 2010a, Clark et al. 2018).

Demographic studies indicate an unusually low per capita recruitment of two-year old adults to the breeding population, while other demographic rates are similar to those of other small calidrids (Zöckler et al. 2010a). This finding suggests that the major external drivers of the population decline are factors affecting the mortality rate of immature birds, such as loss of intertidal habitat at migration stopover sites and hunting on the wintering grounds (Zöckler et al. 2010b, 2016, Chowdhury 2012, Tong et al. 2012, Piersma et al. 2016, Peng et al. 2017, Choi et al. 2018). Spoon-billed Sandpipers are caught as bycatch during mist-netting of larger species of shorebirds at several sites in Myanmar, Bangladesh and China (Bird et al. 2010, Chowdhury 2010, Zöckler et al. 2010b, Martinez and Lewthwaite 2013, Pyae-Phyo et al. 2018). There have already been some successful conservation interventions, discouraging hunting at known sites (Bird et al. 2010, Clark et al. 2014, Zöckler et al. 2016).

Spoon-billed Sandpipers utilise estuarine mudflats at migration stopovers and on the wintering grounds (Tong et al. 2012). In recent decades, large expanses of these mudflats have been lost to land claim and development (Melville et al. 2016, Peng et al. 2017, Studds et al. 2017), with loss in the East Asian-Australasian flyway estimated to occur at 1.66\% per annum (Murray and Fuller 2015). Remaining intertidal habitat at stopover sites is further threatened by the encroachment of the invasive grass Spartina alterniflora, which traps sediment accelerating conversion of mudflats to dry land (Peng et al. 2017). Areas of intertidal mudflat have an inherently patchy distribution along the coast and losses restrict the stopover sites available for migrating birds, likely increasing energetic demands, limiting food supplies and rendering the birds more vulnerable to stochastic events such as storms (Sutherland et al. 2012, Murray et al. 2014, Studds et al. 2017, Wang et al. 2020).

Surveys of individually marked birds at stopover sites indicates that up to $50 \%$ of the global population has not been located at wintering sites using traditional field survey techniques (Zöckler et al. 2016, Clark et al. 2018). Satellite tracking studies have located previously unknown migration 
stopover and wintering locations (Chang and Clark 2018), but tags are expensive and only a small number of birds can be tracked, which means that not all wintering sites will be detected by this method. Hence, it is important to develop other approaches to identify additional staging and wintering locations to identify where protected areas are needed and target conservation interventions.

Species distribution modelling is an established tool in conservation and is used to identify potentially important - but hitherto unconfirmed - areas utilised by threatened species (Franklin 2010). It has previously been used to model the core wintering area for Spoon-billed Sandpipers, and successfully confirmed important known wintering sites, namely the Gulf of Mottama and the Inner Gulf of Thailand (Zöckler et al. 2016). The predicted winter distribution also highlighted a previously unknown site in the Ganges-Brahmaputra Delta (Zöckler et al. 2016), a location since proven to support a substantial wintering population (Chowdhury et al. 2018). However, the geographic scope of Zöckler et al. (2016) was limited. New sites in India, Sri Lanka, and Indonesia have recently been found to support Spoon-billed Sandpipers, indicating potentially suitable sites remain to be discovered in the wintering range. Additionally, Zöckler et al. (2016) focused on only part of the species' non-breeding distribution and did not examine the potential distribution of stopover sites between south-east Asia and Arctic Russia.

Since Zöckler et al.'s (2016) analysis, many more Spoon-billed Sandpiper records have been gathered from a much wider area. A combination of field surveys at wintering and stopover sites, and a small number of satellite-tagged birds, yielded 2,798 new observations between 2015 and 2017. Here we produce species distribution models to identify the areas that might be suitable for Spoon-billed Sandpipers along the entire migratory route and a wider potential wintering distribution area than examined by Zöckler et al. (2016). We then compare these predictions with protected area coverage. In $2008,17 \%$ of sites known to be occupied by non-breeding Spoon-billed Sandpiper were covered by protected area designations (Zöckler et al. 2008). However, the number of designated sites in the flyway has increased substantially in recent years (UNEP-WCMC, IUCN and NGS 2018), requiring a reassessment of how much Spoon-billed Sandpiper habitat is protected. Findings from the models will both inform future survey efforts and help to target conservation interventions.

\section{Methods}

\section{Study regions}

The passage and wintering distribution of Spoon-billed Sandpiper is extensive, spanning Arctic Russia to tropical south-east Asia. Consequently, conditions change markedly across their migration and wintering areas. Thus, we divided the study area into three regions (Figure 1 ). The south region (between $6^{\circ} \mathrm{S}$ and $30^{\circ} \mathrm{N}$ latitude) is where the birds predominantly winter, between early November and late February. This was bounded between $76^{\circ}$ and $130^{\circ} \mathrm{E}$ (i.e. southern tip of India to eastern Indonesia, excluding the island of New Guinea), these longitudinal and southern limits extend beyond all historical records for the species. The central region $\left(30^{\circ}-40^{\circ} \mathrm{N}\right)$ covers the core stopover sites. These sites are used during spring (northwards) migration between early March and mid-June, and then again during the post-breeding (southwards) migration between mid-August and late October. The north region $\left(40^{\circ}-63^{\circ} \mathrm{N}\right)$ is visited by migrating birds immediately before and after the breeding season, birds are present between mid-June and mid-August. Immature birds sometimes spend their first summer on wintering grounds, before returning to the north to breed as second-year birds (Zöckler et al. 2010a).

\section{Spoon-billed Sandpiper records}

Location records came from two data sources: field observations and satellite tracking. Field observations of Spoon-billed Sandpipers made by experienced surveyors were conducted at passage 


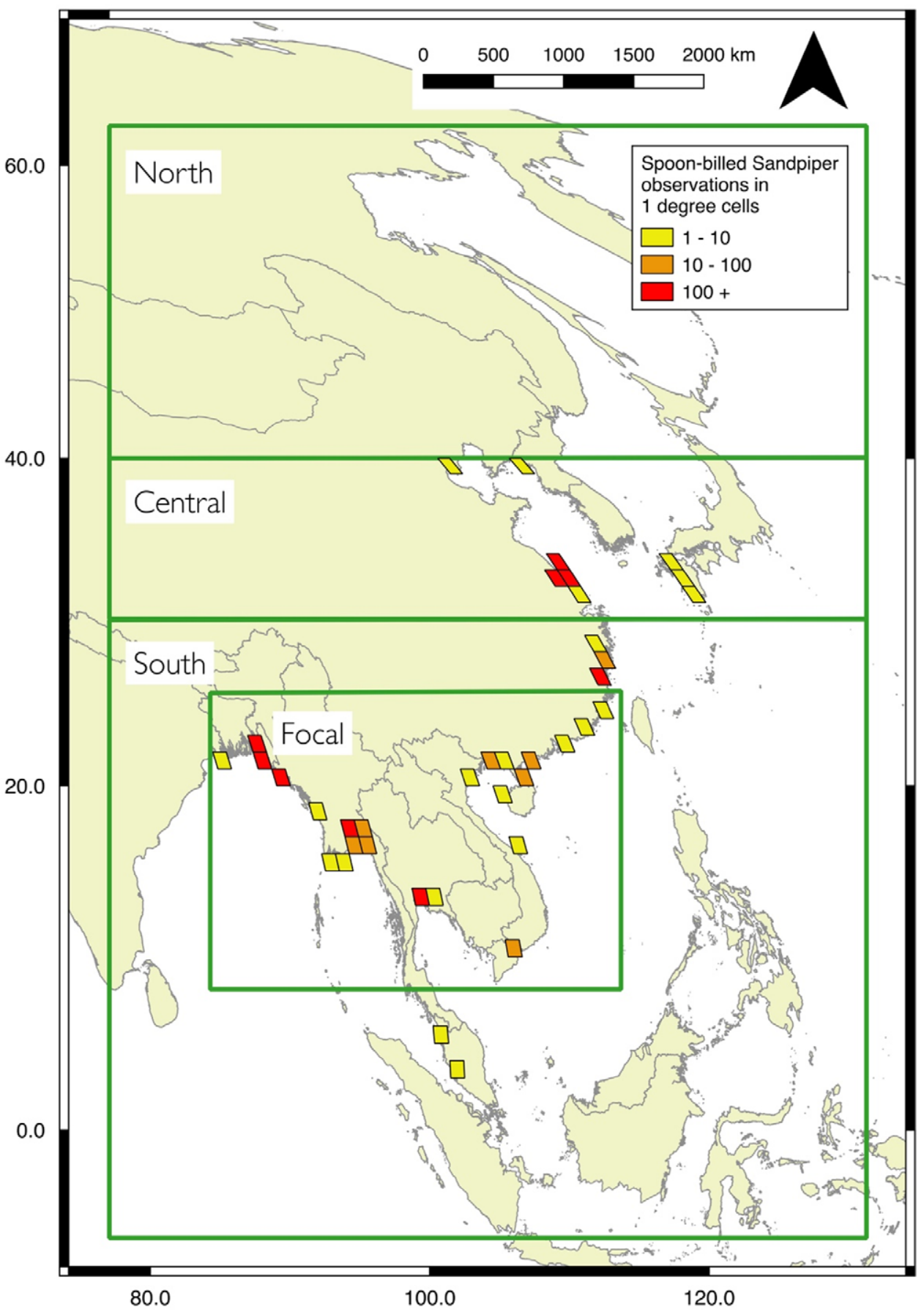

Figure 1. The potential non-breeding range of spoon-billed sandpiper, showing the three main regions used in this study: north, central and south. For the south region, the distribution model was initially built with the focal region, before extrapolation to the whole area. Number of Spoonbilled Sandpiper records from field surveys 2008-2017 in the central and south regions are shown in 1 degree squares, records from field surveys in the north region were not available. 
and wintering sites located in the south and central regions between 2008 and 2017 (Figure 1 ). Field surveys have been conducted in the north region, but records were not available for modelling. Sites were selected for surveys either because they were known to be occupied from earlier records, or because occupation was considered possible based upon the presence of extensive tidal mud flats (Zöckler et al. 2016). Given the highly dynamic nature of mudflats and the habitat losses that have occurred in some areas, we limited data to recent records (i.e. 2008-2017) as site suitability may have changed over a longer period. We sought to produce a distribution model that would inform future monitoring and protection rather than map historic use. There were 5,148 field observations of Spoon-billed Sandpipers from 544 pixels of 500 x $500 \mathrm{~m}\left(0.25 \mathrm{~km}^{2}\right.$; see below).

Nine birds were fitted with satellite tags (Microwave Telemetry Inc, Maryland, USA) at various stages in the annual cycle: three in autumn 2016, two in spring 2017, three in summer 2017 and one in autumn 2017 (Chang and Clark 2018). Each bird provided data for a different part of the year, but in combination cover the entire migratory flyway. These tracking data provided additional records for known sites, and pinpointed locations used by Spoon-billed Sandpipers where field surveys were not conducted. Fix accuracy is classified at moment of capture, and for this study we only used fixes with a location error of less than $1,500 \mathrm{~m}$. This provided 1,107 fixes from a total of $4770.25 \mathrm{~km}^{2}$ pixels, so that the total dataset used for the modelling contained 1,021 occupied $0.25 \mathrm{~km}^{2}$ pixels.

\section{Satellite imagery of study regions}

We focused on coastal areas in the study regions and used country polygons from gadm.org (version 3.6) as the basis for the coastline. Given Spoon-billed Sandpiper preference for dynamic areas of coastline, we visually compared the gadm.org coastline against 2017 Sentinel 2 satellite remote sensing data with a spatial resolution of $10 \mathrm{~m}$ and modified the coastline where appropriate (ESA 2018). Of the 6,492 Spoon-billed Sandpiper records available from surveys and satellite tags, $85 \%$ were from the seaward side of the coastline, with the remainder inland. We therefore restricted the study focus to $5 \mathrm{~km}$ onshore and $30 \mathrm{~km}$ offshore of the coastline, this area included $96 \%$ of the total number of records (i.e. 6,255 records, comprised the 5,148 observations and 1,107 tag fixes described above). The much wider area of sea was included because Zöckler et al. (2016) found that offshore conditions were important predictors of Spoon-billed Sandpiper presence, particularly ocean chlorophyll, which is potentially related to inshore conditions associated with photosynthetic activity in estuaries and tidal mudflats.

We utilised Google Earth Engine (https://earthengine.google.com) to access and download the satellite imagery for the buffered coastline in each of the three regions. For the distribution models, we selected Sentinel I synthetic aperture radar data (ESA 2018), and 8-day composite surface reflectance scenes from MODIS (Vermote 2015). Radar was included as a proxy for separating mudflat characteristics (van der Wal et al. 2005) and was resampled to $0.25 \mathrm{~km}^{2}$ to match the resolution of the MODIS imagery. The MODIS product includes seven bands that span wavelengths of 459 to $2,155 \mathrm{~nm}$ (Table 1). We restricted imagery to the twelve months between November 2016 and October 2017. Imagery for each region was limited to the period in which Spoon-billed Sandpipers are generally present: south, O1/11/2016-28/02/2017, central Spring, 01/03/2017 - 14/06/2017, north, 15/06/2017 - 15/08/2017, and, central Autumn, 16/08/2017 $31 / 10 / 2017$. Some adult birds spend the entire winter in the central region, while some first-year birds remain in the central region rather than migrating north in the breeding season (Chang and Clark 2018). Spoon-billed Sandpiper may therefore be present throughout the year in the central region, but we focused on potential distribution during the stopover periods as this is when most birds are present. We selected the mean pixel values from the time period for each region. We used Sentinel I radar, all seven MODIS bands, and MODIS-derived Normalised Difference Vegetation Index (NDVI) to give a total of nine variables for the modelling.

To determine whether sites identified by the model are recognised as being important for wildlife, we compared model outputs with coverage of Key Biodiversity Areas (KBAs) and 
Table 1. Importance of each variable in the four regional models, "-" indicates variable dropped during model construction. "Percent contribution" shows the relative contribution of each variable when it is included in the final model, "Permutation importance" shows the percentage fall in training AUC when values for that variable are randomly permuted while other variables are left unchanged.

\begin{tabular}{|c|c|c|c|c|c|c|c|c|}
\hline \multirow[b]{2}{*}{ Variable } & \multicolumn{2}{|c|}{ North } & \multicolumn{2}{|c|}{ Central Autumn } & \multicolumn{2}{|c|}{ South } & \multicolumn{2}{|c|}{ Central Spring } \\
\hline & $\begin{array}{l}\text { Percent } \\
\text { contribution }\end{array}$ & $\begin{array}{l}\text { Permutation } \\
\text { importance }\end{array}$ & $\begin{array}{l}\text { Percent } \\
\text { contribution }\end{array}$ & $\begin{array}{l}\text { Permutation } \\
\text { importance }\end{array}$ & $\begin{array}{l}\text { Percent } \\
\text { contribution }\end{array}$ & $\begin{array}{l}\text { Permutation } \\
\text { importance }\end{array}$ & $\begin{array}{l}\text { Percent } \\
\text { contribution }\end{array}$ & $\begin{array}{l}\text { Permutation } \\
\text { importance }\end{array}$ \\
\hline $\begin{array}{l}\text { MODIS Band } 1 \\
\quad(620-670 n m)\end{array}$ & 15.8 & 1.1 & 50.6 & 22.8 & 13 & 43 & 34.6 & $3 \cdot 9$ \\
\hline $\begin{array}{l}\text { MODIS Band } 2 \\
\quad(841-876 \mathrm{~nm})\end{array}$ & 2.4 & 0.9 & $15 \cdot 7$ & 11.9 & 36 & $3 \cdot 3$ & 31 & 36.3 \\
\hline $\begin{array}{l}\text { MODIS Band } 3 \\
\quad(459-479 n m)\end{array}$ & 31 & 40.7 & $13 \cdot 7$ & 2.5 & $15 \cdot 7$ & 21.2 & 4.2 & 1.6 \\
\hline $\begin{array}{l}\text { MODIS Band } 4 \\
\quad(545-565 \mathrm{~nm})\end{array}$ & $9 \cdot 9$ & $35 \cdot 4$ & - & - & - & - & 1.6 & 2.5 \\
\hline $\begin{array}{l}\text { MODIS Band } 5 \\
\quad(1230-1250 \mathrm{onm})\end{array}$ & 8.5 & $9 \cdot 4$ & 6.8 & 19.7 & 13.8 & 18.6 & 12.8 & 35.6 \\
\hline $\begin{array}{l}\text { MODIS Band } 6 \\
\qquad(1628-1652 \mathrm{~nm})\end{array}$ & - & - & 1.3 & 26.6 & 2.9 & $7 \cdot 3$ & $5 \cdot 5$ & 16.8 \\
\hline $\begin{array}{l}\text { MODIS Band } 7 \\
\quad(2105-2155 \mathrm{~nm})\end{array}$ & 6.6 & $5 \cdot 3$ & 2.6 & 12.6 & - & - & - & - \\
\hline MODIS NDVI & 17 & $3 \cdot 5$ & - & - & 11 & 4.6 & - & - \\
\hline Sentinel I Radar & 8.7 & 3.8 & $9 \cdot 3$ & $3 \cdot 9$ & $7 \cdot 7$ & 2 & 10.3 & $3 \cdot 3$ \\
\hline
\end{tabular}


Important Bird and Biodiversity Areas (IBAs; BirdLife International 2018). Finally, to assess the level of habitat protection currently covering sites identified by the models, we used data from the World Database on Protected Areas (UNEP-WCMC and IUCN 2018) to overlay protected area boundaries onto our predicted model outputs. We included all designations except UNESCO Man and Biosphere Reserves.

\section{Species distribution modelling}

We used Maximum Entropy to model the species' distribution with MaxEnt (version 3.4.1, Phillips et al. 2018). Pixels with a Spoon-billed Sandpiper record were classed as presences, and 10,000 background points sampled as pseudo-absences. We constructed four models in total, relating to the north, central (Autumn), central (Spring) and south regions (Figure I). Initial models included all nine variables and were refined by stepwise backwards elimination, following each model run, the variable with the lowest relative contribution was dropped until all variables contributed $>_{1} \%$ to the model. Where appropriate, the regularisation multiplier was increased to avoid over-fitting the model to the training data and produce smooth response curves (Phillips et al. 2006). Once a final model for each region was constructed, 10-fold cross-validation resampling was used to assess variable importance (Elith et al. 201I). MaxEnt does not segregate data spatially (Elith et al. 201I), potentially inflating estimates of model accuracy (Bladon et al. 2018). We attempted to minimise inflating model accuracy assessments by using only one record for each occupied $0.25 \mathrm{~km}^{2}$ cell in the models. Model fit was assessed using the AUC (Area Under the receiver-operator Curve) statistic, where a value of 0.5 implies the model is no better than random, while that of 0.9 and above indicates a good fit (Swets 1988).

For the north and central regions, models were constructed for the entire area. For the south region, the model was initially built using a focal area encompassing the principal known wintering sites, corresponding broadly to the area used in Zöckler et al. (2016). This focal model was produced as described above and extrapolated to cover the full south region (Figure 1 ). Following Zöckler et al. (2016), we defined key potential sites as the $5 \%$ of pixels with the highest modelled probability of occupancy.

\section{Results}

Field observations of Spoon-billed Sandpiper came from coastal sites across the central and south regions (Figure I). Distribution was patchy, with the majority of records from just a few sites in the wintering areas: the Meghna estuary and Cox's Bazar in Bangladesh, Nan Thar island and the Gulf of Mottama in Myanmar, the Inner Gulf of Thailand, and Hainan and the Leizhou Peninsula in Guangdong, China. The most important stopover site was the southern Jiangsu coast in China. To an extent this skewed distribution reflects concentrated survey effort at known sites, however the species' association with extensive tidal mudflats means that larger congregations are most probable in these locations.

The high AUC values signified that all four models were adequate descriptions of Spoon-billed Sandpiper distributions (Table 2). This indicates that the predicted outputs could be accurate representations of potential Spoon-billed Sandpiper distributions. Considering individual variables, MODIS bands 1, 2 and 3 (corresponding to visible red, infrared, and blue wavelengths respectively; Table I) were generally the most important in all models, although the importance

Table 2. Summary of the AUC values from the 1o-fold cross-validation analyses for each region model.

\begin{tabular}{llc}
\hline Region & AUC \pm sd & Number of training points \\
\hline North & $0.928 \pm 0.02$ & 151 \\
Central Autumn & $0.968 \pm 0.009$ & 259 \\
South & $0.946 \pm 0.02$ & 179 \\
Central Spring & $0.961 \pm 0.045$ & 100 \\
\hline
\end{tabular}


of each changed among regions (Table I). Band I was the most important for central region models, particularly for the Autumn model. Bands 2 and 5 were notably important for the south and central Spring models, whereas band 3 was the most important for the north model. Radar was retained in all models, contributing between 7.7 and 10.3\%. NDVI was included in models for north and south regions, but dropped from the central region models. MODIS bands 4, 6 and 7 were of low importance across all regions. Response curves and standard deviations of the variables for each model are given in Figure $S_{I}$ in the online supplementary material.

Model outputs for each region are shown in Figures 2 to 4 , with the key sites labelled. For display purposes the $0.25 \mathrm{~km}^{2}$ pixels have been resampled to $10 \mathrm{~km}^{2}$ (full resolution versions are available in Figures $\mathrm{S}_{2}$ to $\mathrm{S}_{5}$ ). Potential sites with a high likelihood of occupancy for Spoon-billed Sandpipers are spread across the north region: near Shelikhova Bay (A), Karaginskiy and Oliutorskiy Bays (B), in Kamchatka, the western coast (C) and the mouth of the Kamchatka river (D), Turgurski and Academy Bays (E), at the mouth of the Amur liman and around northern Sakhalin (F), In the central region, there is a larger area predicted as suitable for Spoon-billed Sandpipers during the Autumn (southward) migration than Spring (northward) migration. However, both autumn and spring models identify three main areas in the Yellow Sea as particularly valuable habitat: Bohai and Laizhou Bays $(\mathrm{G})$, the Jiangsu coast $(\mathrm{H})$, and the Yangtze Delta and Hangzhou Bay (J), either side of Shanghai. The focal area of the south region identifies the key overwintering sites known to

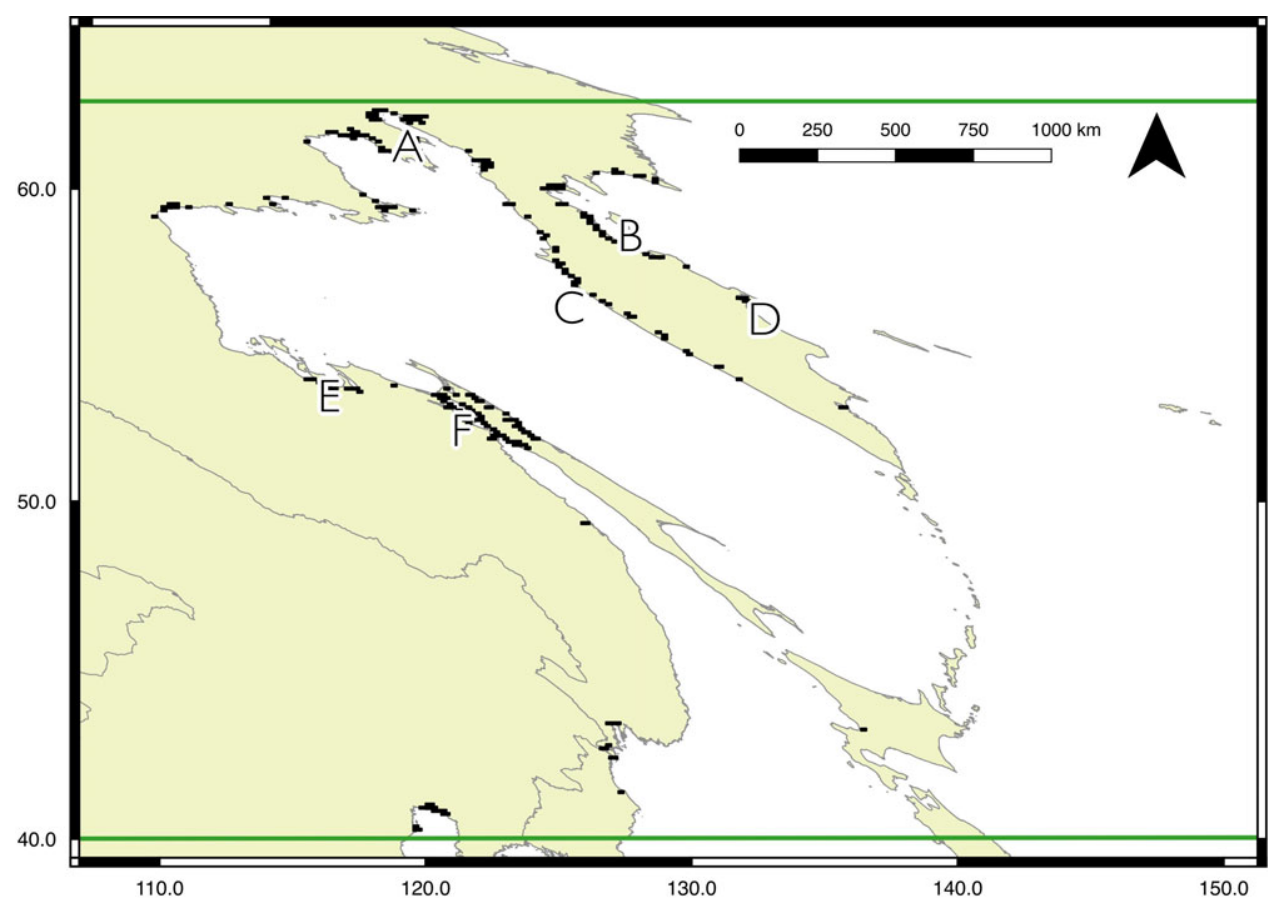

Figure 2. Predicted Spoon-billed Sandpiper distribution for the north region, bounded by horizontal lines shown at $40^{\circ}$ and $63^{\circ} \mathrm{N}$. For display purposes $500-\mathrm{m}$ pixels were resampled to $10-\mathrm{km}$ squares, and the $5 \%$ of squares with the highest likelihood of occupancy are shown. A full resolution version of the map is available in the online materials (Figure S2). Sites predicted to be suitable for the species are labelled thus: A - Shelikhova Bay, B - Karaginskiy and Oliutorskiy Bays, C - Western Kamchatka coast, D - Kamchatka river mouth, E - Tugurski and Academy Bays, F - Amur liman and Northern Sakhalin. Details of these sites, with coordinates and protected area status are available in Table $\mathrm{S}_{1}$. 


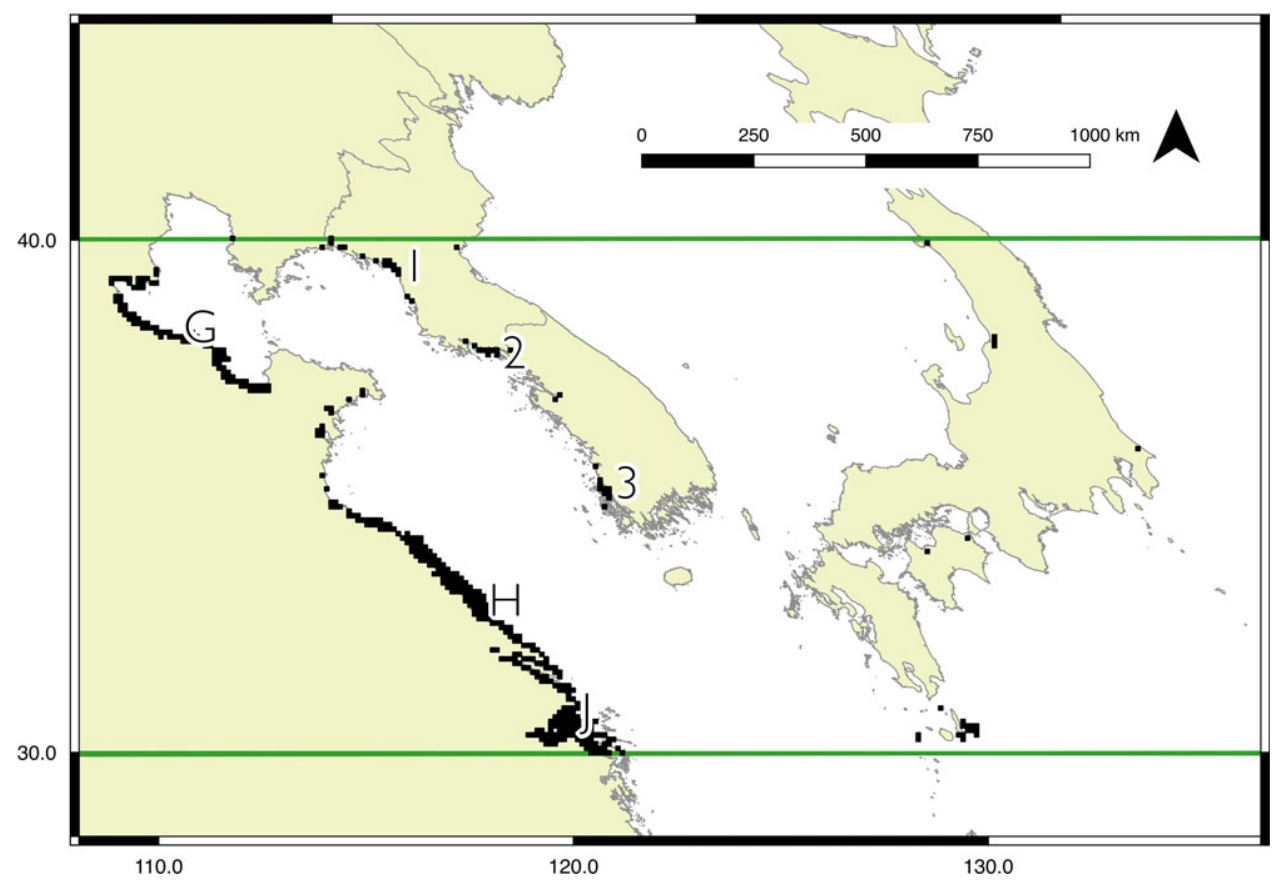

Figure 3. Predicted Spoon-billed Sandpiper distribution for the central region during migration, bounded by horizontal lines shown at $30^{\circ}$ and $40^{\circ} \mathrm{N}$. For display purposes $500-\mathrm{m}$ pixels were resampled to $10-\mathrm{km}$ squares, and the $5 \%$ of squares with the highest likelihood of occupancy are shown. At this scale there is no change between the Autumn and Spring migration in the areas most likely occupied. However, a full resolution version of these maps are available in the online materials that show some subtle differences between the two time periods (Figures $\mathrm{S}_{3}$ and $\mathrm{S}_{4}$ ). Key sites known to be occupied are labelled thus: G - Bohai and Laizhou Bays, H - Jiangsu coast, J Yangtze Delta and Hangzhou Bay near Shanghai. Sites predicted to be suitable by the model that have not been formally surveyed: 1 - coast at Pyongyang, 2 - Yonan coast, 3 - Jeollanam-do coast. Details of labelled sites with coordinates and protected area status are available in Table $\mathrm{S}_{1}$.

support Spoon-billed Sandpiper, namely the Ganges-Brahmaputra Delta (M), the Rakhine coast and Nan Thar island (N), Hainan and the western Guangdong coast (P), the Gulf of Mottama and Ayeyarwady Delta (Q), the Inner Gulf of Thailand (R), and the Mekong Delta (S). The model for the wider south region also highlights sites where Spoon-billed Sandpipers were seen in 2018: Mannar in Sri Lanka (K), Fraserganj in India (L), and Aceh in Indonesia (T).

Protected areas listed in the 2018 version of the WDPA cover only $8 \%$ of the most likely occupied locations in the non-breeding range of Spoon-billed Sandpiper. Of the top $5 \%$ of areas most likely to be occupied, $15 \%$ of the north region, $10 \%$ of the central region and $5 \%$ of the south region are covered by protected areas. KBA and IBA coverage is slightly greater, covering $13 \%$ of the most likely occupied locations. In the north region $26 \%$ of sites are covered, $15 \%$ in the central region and $10 \%$ in the south.

\section{Discussion}

\section{Spoon-billed Sandpiper distribution}

This study is the first to combine field observations and satellite tracking data of the Critically Endangered Spoon-billed Sandpiper to identify areas with a high likelihood of occupancy across the 


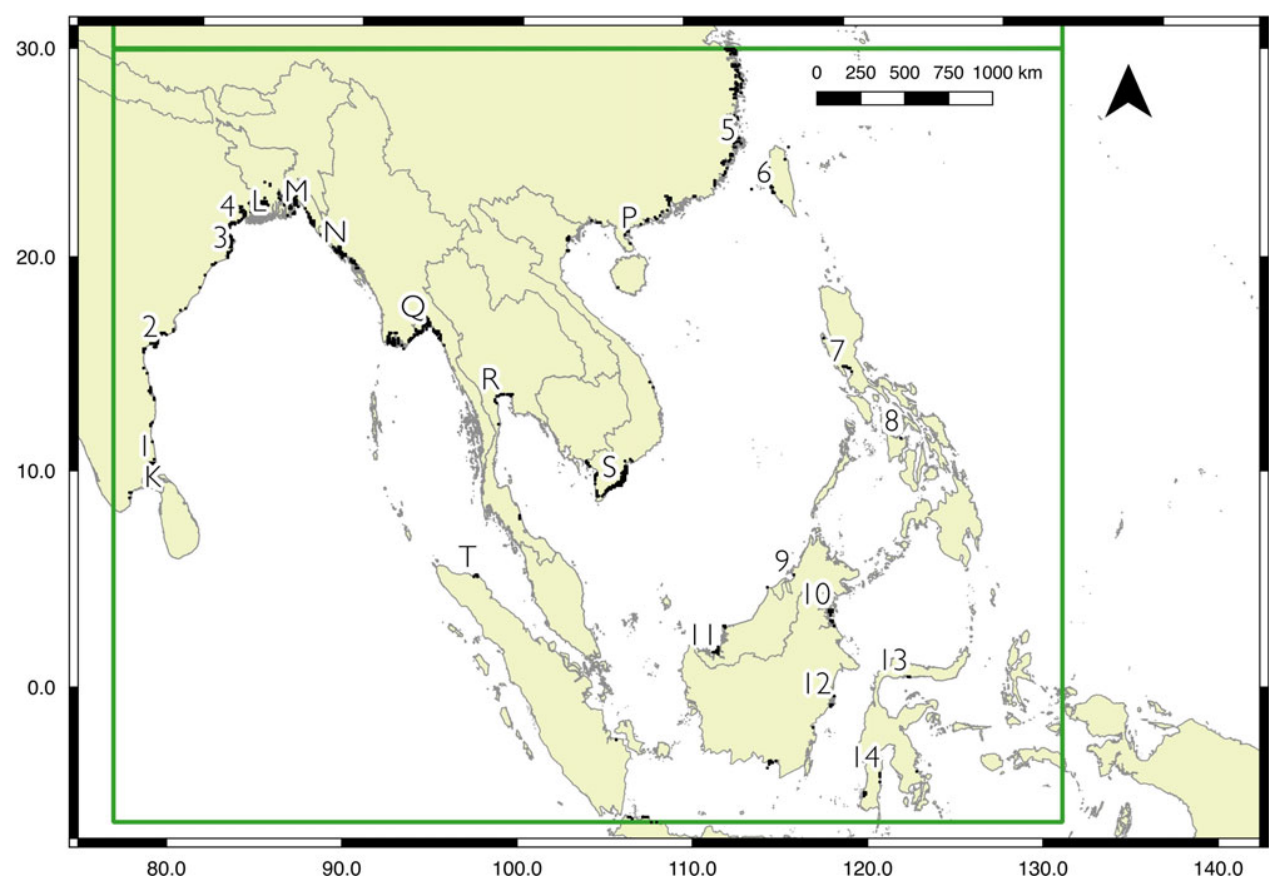

Figure 4. Predicted Spoon-billed Sandpiper distribution for the south region, bounded by the box between $6^{\circ} \mathrm{S}$ and $30^{\circ} \mathrm{N}$, and between $76^{\circ}$ and $130^{\circ} \mathrm{E}$. For display purposes $500-\mathrm{m}$ pixels were resampled to $10-\mathrm{km}$ squares, and the $5 \%$ of squares with the highest likelihood of occupancy are shown. A full resolution version of the map is available in the online materials (Figure $\mathrm{S}_{5}$ ). Sites known to be occupied are labelled thus: K - Mannar in Sri Lanka, L - Fraserganj in India, M Ganges-Brahmaputra Delta, N - Rakhine coast and Nan Thar island, P - Hainan and the Leizhou Peninsula, Guangdong, Q - Gulf of Mottama and the Ayeyarwaday Delta, R - Inner gulf of Thailand, S - Mekong Delta, and T - Aceh in Indonesia. Sites predicted by the model to be occupied that have either not been formally surveyed between 2008 and 2017, or have never been assessed: I - Point Calimere, 2 - Khrishna river, 3 - Lake Chilika and Mahanadi river, 4 - Hooghly river, 5 Fujian coast, 6 - South-west coast of Taiwan, 7 - Manilla Bay, 8 - Mindoro and Panay, 9 - Brunei Bay, 10 - Kayan river, 11 - Maludam National Park, 12 - Mahakam river, 13 - Gorontalo coast, 14 South Sulawesi. Details of labelled sites with coordinates and protected area status are available in Table Si.

entire potential non-breeding range. The models identified many potential sites that have not been formally surveyed for Spoon-billed Sandpiper and highlighted the paucity of conservation designations covering key locations throughout the flyway.

All models had high AUC values, suggesting they were appropriate for the prediction of Spoonbilled Sandpiper distribution. The main areas known to be occupied by birds in the north and central regions were successfully identified by the models. The south model highlighted all the known sites, and there is strong agreement with Zöckler et al. (2016) in identifying the most important sites in the core wintering range. Moreover, the model performed well in mapping the potential distribution of the species in new areas, successfully identifying locations only recently found to be occupied such as Mannar in Sri Lanka and Fraserganj in India (Chakraborty et al. 2018, Darshana 2018), although the latter might only serve as a stopover site as extensive winter surveys in the past did not record Spoon-billed Sandpiper (Zöckler et al. 2005). 
Identification of new populations or new areas of suitable habitat is frequently cited as one of the purposes of species distribution models. Encouragingly, earlier attempts to model Spoon-billed Sandpiper distribution resulted in discovery of previously unknown occupied sites (Zöckler et al. 2016, Chowdhury et al. 2018). The models presented in this study highlighted numerous potential passage sites, and the findings can be used for planning future formal survey efforts. Details of occupied and potential sites, with coordinates and protected area status are available in Table $\mathrm{S}_{1}$. The majority of potential locations in the north region are in the vicinity of areas previously identified as stopover sites for Spoon-billed Sandpiper and a range of other shorebird species (Antonov and Huettmann 2004, Gerasimov 2006, Tomkovich et al. 2013, Aharon-Rotman et al. 2016). However, there are several sites around the Shelikhova Gulf that merit further investigation, including Gizhiga, Mametchinskiy and Rikiniki Bays. In the central region the most likely candidates for previously unrecognised sites are on the west coast of the Korean peninsula. In the Democratic People's Republic of Korea there is a small area close to Pyongyang, and a large stretch of coastline in Yonan county. Satellite tagging data from two birds has since shown Yonan to be an important moulting site for Spoon-billed Sandpiper (Green et al. 2018). In the Republic of Korea there are extensive areas of tidal flats on the Jeollanam-do coast and the west coast of the Republic of Korea is already known to support internationally important concentrations of wading birds (Moores 1999, 2006, RSIS 2018), although Spoon-billed Sandpipers have not yet been recorded there.

In the south region there are numerous potential areas that merit formal surveying. Stretches of the east coast of India were identified with a high potential for occupation: between the Hooghly and Mahanadi rivers, north of the Khrishna river, and at Point Calimere in the far south. There are historic records of Spoon-billed Sandpiper from both Point Calimere and the Lake ChilikaMahanadi Delta area, all sites that host large numbers of other migratory waterbirds (Balachandran 2006, Ghosh et al. 2006, RSIS 2018). The Fujian coastline in China, and Changhua and Tainan counties on the west coast of Taiwan all have a high likelihood of occupancy. There are informal, historic records of Spoon-billed Sandpiper from these areas (Bunting and Zöckler 2006, eBird 2018), and the species was successfully recorded during surveys in Fujian in 2019. Wenzhou Bay in Zhejiang also appears suitable and has recently been found to be an important stopover site for Great Knot Calidris tenuirostris (Chan et al. 2019). In the Philippines, Manila Bay, the south end of Mindoro, and parts of Panay all appear highly suitable, although there are no records of Spoon-billed Sandpiper from these areas. There are several prospective areas in Borneo, including Brunei Bay IBA, the Sadong-Saribas coast IBA in Sarawak, and the Kayan and Mahakam river estuaries on the East coast of Kalimantan. In Sulawesi there are small areas in the Tanjung Panjang KBA on the south coast of Gorontalo province, and on both east and west coasts of South Sulawesi. The sites in Borneo and Sulawesi are more speculative as there are no records for the species on these islands, although many of the sites are recognised as important for other shorebird species (BirdLife International 2018).

\section{Conservation implications}

Intertidal habitats on the East Asian-Australasian flyway are imperilled by a range of threats including pollution, invasive species, sea level rise, habitat loss and hunting (Studds et al. 2017, Sutherland et al. 2012). In the case of habitat loss for example, over 40,000 ha of intertidal flats were destroyed at the Saemangeum estuary in the Republic of Korea following construction of a $33 \mathrm{~km}$ long sea wall (Rogers et al. 2006). This had dramatic consequences for wading bird populations in the area, up to 200 Spoon-billed Sandpipers were recorded during the 1990s, but once the estuary was enclosed in 2006, this dropped to only three individuals (Barter 2002, Moores et al. 2008, 2016). Austral migrant wading bird species reliant on stopover sites in the Yellow Sea have undergone severe declines in recent decades, arguably as a result of habitat loss and disturbance (Studds et al. 2017). Despite documented declines in site quality in the Yellow Sea, many species have not shifted from traditional areas, implying a lack of alternatives (Zhang et al. 2018). Given 
commonalities in ecology, Spoon-billed Sandpiper are likely impacted in a similar way, threatened by declining habitat quality but unable to shift to alternative sites.

Such strong site limitation during migration emphasises the precarious situation of Spoon-billed Sandpiper and the species' sensitivity to further habitat disturbance or destruction. In consequence, recognised staging sites such as the Jiangsu coast are critically important, as the entire population may stop over at these sites during spring and autumn migration. These stopover sites are vital links in the species' movements along the East Asian-Australasian flyway, and loss of such sites might consign Spoon-billed Sandpipers to extinction (Tong et al. 2012). Furthermore, sites predicted to have a high likelihood of occupancy by Spoon-billed Sandpiper are also likely to be used by other wading bird species of conservation concern such as the Endangered Nordmann's Greenshank Tringa guttifer and Great Knot, increasing sites' importance for biodiversity conservation generally (Zöckler et al. 2018).

Preventing declines and extinctions of wading bird species in the East Asian-Australasian Flyway would be assisted by a cohesive network of protected areas. Throughout the East AsianAustralasian flyway, there is growing governmental recognition of the need to protect threatened coastal areas. China recently initiated new environmental protection legislation, declaring that strict controls would be placed on land claim projects in the Yellow Sea area (State Council 2018) and nominating priority Yellow Sea coastal wetlands as Natural World Heritage Sites (UNESCO World Heritage Centre 2017). New Ramsar sites have also been designated in Myanmar and the Republic of Korea amongst others (RSIS 2018). However, only a small fraction of the locations potentially suitable for Spoon-billed Sandpiper are currently covered by nature conservation designations. While it is unfeasible to protect or manage every potentially suitable location, many of the areas deemed most likely occupied but as yet without Spoon-billed Sandpiper records are IBAs, and therefore recognised for their importance for wider biodiversity. Unfortunately, IBAs often have little or no formal protection (BirdLife International 2018).

Given the level of threats faced by Spoon-billed Sandpipers and other wading birds in the flyway, existing protected areas must be respected. Unprotected, but potentially highly suitable sites should be surveyed for Spoon-billed Sandpiper as soon as possible, in order to guide site-based conservation management, including expansion of the protected area network (Zhang et al. 2017). Further conservation interventions should be encouraged, education and advocacy work has proven effective at reducing hunting pressures in known areas (Bird et al. 2010, Htin Hla and Eberhardt 2011, Chowdhury 2012, Clark et al. 2014). However, for these to be successful in the longer term, outside engagement must be maintained, and supported by funding for alternative livelihoods (Chowdhury 2010, Pyae Phyo et al. 2018). The distribution models presented here identify priority areas for future surveying, and conservation intervention and protection.

\section{Supplementary Materials}

To view supplementary material for this article, please visit http://dx.doi.org/10.1017/ So959270920000398.

\section{Acknowledgements}

Our thanks to the many surveyors who conducted the field surveys throughout the non-breeding range. The Satellite tagging team is a collaboration between Birds Russia, Nanjing Normal University, RSPB, WWT, BTO, SBS TF and many individuals. Tracking data were curated by WWT. We are grateful to two anonymous referees for their helpful comments.

Field surveys in Russian non-breeding grounds were supported by RSPB, MHS and NABU. Field surveys in Gulf of Mottama were partly supported by BBC Wildlife Fund. Satellite tagging data collection was partly supported by The Biodiversity Investigation, Observation and Assessment Program (2019-2023) of the Ministry of Ecology and Environment of China, RSPB and a private donor. Bangladesh Spoon-billed Sandpiper Conservation Project's fieldwork in Meghna Estuary 
(2015-2016) was supported by RSPB. Data collection by EL was partly supported by Basic research program (budgetary funds), projects number AAAA-A19-119022190168-8 and AAAA-A19119021990093-8). PT was supported by Moscow State University Grant for Leading Scientific Schools "Depository of the Living Systems" in the MSU Development Program framework. TBL was funded by the Natural Environment Research Council UK and the IAPETUS Doctoral Training Partnership.

\section{References}

Aharon-Rotman, Y., Bauer, S. and Klaassen, M. (2016) A chain is as strong as its weakest link: Assessing the consequences of habitat loss and degradation in a long-distance migratory shorebird. Emu 116: 199-207.

Antonov, A. and Huettmann, F. (2004) On the southward migration of Great Knot in the western Sea of Okhotsk: results and conclusions from coordinated surveys of northern Sakhalin island and Schastia bay, 2002. The Stilt 45: 14-20.

Balachandran, S. (2006) The decline in wader populations along the east coast of India with special reference to Point Calimere, south-east India. Pp. 296-301 in G. C. Boere, C. A. Galbraith and D. A. Stroud, eds. Waterbirds around the world. Edinburgh, UK: The Stationery Office.

Barter, M. (2002). Shorebirds of the Yellow Sea: Importance, threats and conservation status. Canberra, Australia: Wetlands International Global Series 9, International Wader Studies 12.

Bird, J. P., Lees, A. C., Chowdhury, S. U., Martin, R. and Haque, E. U. L. (2010) A survey of the Critically Endangered Spoon-billed Sandpiper Eurynorhynchus pygmeus in Bangladesh and key future research and conservation recommendations. Forktail 26: 1-8.

Bladon, A. J., Donald, P. F., Jones, S. E., Collar, N. J., Deng, J., Dadacha, G., Abebe, Y. D. and Green, R. E. (2018) Behavioural thermoregulation and climatic range restriction in the globally threatened Ethiopian Bush-crow Zavattariornis stresemanni. Ibis 161: 546-558.

BirdLife International (2017) Spoon-billed Sandpiper Calidris pygmaea. The IUCN Red List of Threatened Species 2017. Accessed online 2nd December 2018 from dx.doi.org/10.2305/IUCN.UK.2018-2.RLTS. T22693452A134202771.en
BirdLife International (2018) The World Database of Key Biodiversity Areas. Developed by the Key Biodiversity Areas Partnership: BirdLife International, IUCN, Amphibian Survival Alliance, Conservation International, Critical Ecosystem Partnership Fund, Global Environment Facility, Global Wildlife Conservation, NatureServe, Royal Society for the Protection of Birds, World Wildlife Fund and Wildlife Conservation Society. Accessed online 2nd December 2018 from www.keybiodiversityareas.org

Bunting, G. and Zöckler, C. (2006) The development of a database for the Spoon-billed Sandpiper Eurynorhynchus pygmeus. Pp. 501-502 in G. C. Boere, C. A. Galbraith and D. A. Stroud, eds. Waterbirds around the world. Edinburgh, UK: The Stationery Office.

Chakraborty, A., Tripathi, S. and Bhattacharya, B.B. (2018) Rediscovery of the Spoon-billed Sandpiper Calidris pygmaea on the coast of West Bengal, India. Indian BIRDS 14: 83-84.

Chan, Y.-C., Tibbets, T. L., Lok, T., Hassell, C. J., Peng, H.-B., Ma, Z., and Piersma, T. (2019) Filling knowledge gaps in a threatened shorebird flyway through satellite tracking. J. Appl. Ecol. 56: 2305-2315.

Chang, Q. and Clark, N. A. (2018) Satellite tagging Spoon-billed Sandpipers in China reveals the importance of the South China Coast. Spoon-billed Sandpiper Task Force News Bull. 18: 16-18.

Choi, C. Y., Jackson, M. V., Gallo-Cajiao, E., Murray, N. J., Clemens, R. S., Gan, X. and Fuller, R. A. (2018) Biodiversity and China's new Great Wall. Divers. Distrib. 24: 137-143.

Chowdhury, S. U. (2010) Preliminary survey of shorebird hunting in five villages around Sonadia Island, Cox's Bazar, Bangladesh. BirdingASIA 14: 101-102. 
Chowdhury, S. U. (2012) Survey and conservation of the critically endangered Spoonbilled Sandpiper in Bangladesh. Ibis 154: 210-211.

Chowdhury, S. U., Foysal, M., Diyan, M. A. A. and Ahmed, S. (2018) Discovery of an important wintering site of the Critically Endangered Spoon-billed Sandpiper Calidris pygmaea in the Meghna Estuary, Bangladesh. Bird Conserv. Internatn. 28: 251-262.

Clark, N., Pain, D. and Green, R. (2014) Saving the spoon-billed sandpiper: an update on the conservation programme. British Birds 107: 74-75.

Clark, N. A., Anderson, G. Q. A., Li, J., Syroechkovskiy, E. E., Tomkovich, P. S., Zöckler, C., Lee, R. and Green, R. E. (2018) First formal estimate of the world population of the Critically Endangered Spoon-billed Sandpiper Calidris pygmaea. Oryx 52: 137-146.

Darshana, T. W. R. (2018) Rediscovery of the Spoon-billed Sandpiper Calidris pygmaea in Sri Lanka after 40 years. Indian BIRDS 14: 111-112.

eBird (2018) eBird: An online database of bird distribution and abundance [web application]. Ithaca, New York: Cornell Lab of Ornithology. Accessed online 1oth September 2018 from www.ebird.org

Elith, J., Phillips, S. J., Hastie, T., Dudík, M., Chee, Y. E., and Yates, C. J. (2011) A statistical explanation of MaxEnt for ecologists. Divers. Distrib. 17: 43-57.

ESA (2018) Copernicus Sentinel satellite imagery [Data set]. European Space Agency, https://sentinel.esa.int

Flint, V. E. and Kondratiev, A. Y. (1977) An experience of evaluating of the total number of a rare stenotypic species (Spoon-billed Sandpiper Eurynorhynchus pygmeus as an example). P. 250 in M. A. Voinstvenski, ed. 7 th All-Union Ornithology Conference, Abstracts of talks Part 2. Kiev, Naukova Dumka. (In Russian).

Franklin, J. (2010) Mapping species distributions: spatial inference and prediction. Cambridge, UK: Cambridge University Press.

Gerasimov, Y. N. (2006) Shorebird migration studies in Kamchatka. Pp. 316-318 in G. C. Boere, C. A. Galbraith and D. A. Stroud, eds.
Waterbirds around the world. Edinburgh, UK: The Stationery Office.

Ghosh, A. K., Pattnaik, A. K. and Ballatore, T. J. (2006) Chilika Lagoon: Restoring ecological balance and livelihoods through re-salinization. Lakes and Reservoirs: Research and Management 11: 239-255.

Green, R. E., Clark, N., Anderson, G., Weston, E. and Hughes, B. (2018) Satellite tagging of spoon-billed sandpipers reveals the importance of intertidal habitats in the Democratic People's Republic of Korea for migration and post-breeding moult. Spoon-billed Sandpiper Task Force News Bull. 19: 31-33.

Htin Hla, T. and Eberhardt, K. (2011) New hope from Nan Thar Island and Bay of Martaban, Myanmar. Spoon-billed Sandpiper Task Force News Bull. 6: 18-20.

Lappo, E. G., Tomkovich, P. S. and Syroechkovkiy, E. E. (2012) Atlas of breeding waders in the Russian Arctic. Moscow: OOO UF Ofsetnaya Pechat.

Martinez, J. and Lewthwaite, R. W. (2013) Rampant shorebird trapping threatens Spoon-billed Sandpiper Eurynorhynchus pygmeus in south-west Guangdong, China. BirdingASIA 19: 26-30.

Melville, D. S., Chen, Y. and Ma, Z. (2016) Shorebirds along the Yellow Sea coast of China face an uncertain future - A review of threats. Emu 116: 100-110.

Moores, N. (1999) A survey of the distribution and abundance of shorebirds in South Korea during 1998-1999: interim survey. The Stilt 34: 18-29.

Moores, N. (2006) South Korea's shorebirds: a review of abundance, distribution, threats and conservation status. The Stilt 50: 62-72.

Moores, N., Rogers, D. I., Rogers, K. and Hansbro, P. M. (2016) Reclamation of tidal flats and shorebird declines in Saemangeum and elsewhere in the Republic of Korea. Emu 116: 136-146.

Moores, N., Rogers, D., Koh, C. H., Ju, Y. K., Kim, R. H. and Park, M. N. (2008) The 20062008 Saemangeum shorebird monitoring program report. Busan: Birds Korea.

Murray, N. J., Clemens, R. S., Phinn, S. R., Possingham, H. P. and Fuller, R. A. (2014) Tracking the rapid loss of tidal wetlands in the Yellow Sea. Frontiers Ecol. Environ. 12: 267-272 
Murray, N. J. and Fuller, R. A. (2015) Protecting stopover habitat for migratory shorebirds in East Asia. J. Ornithol. 156: 217-225.

Peng, H. B., Anderson, G. Q. A., Chang, Q., Choi, C. Y., Chowdhury, S. U., Clark, N. A., Gan, X., Hearn, R. D., Li, J., Lappo, E. G., Liu, W., Ma, Z., Melville, D. S., Phillips, J. F., Syroechkovskiy, E. E., Tong, M., Wang, S., ... Zöckler, C. (2017) The intertidal wetlands of southern Jiangsu Province, China - globally important for Spoon-billed Sandpipers and other threatened waterbirds, but facing multiple serious threats. Bird Conserv. Internatn. 27: 305-322.

Phillips, S. J., Anderson, R. P. and Schapire, R. E. (2006) Maximum entropy modelling of species geographic distributions. Ecol. Modell. 190: 231-259.

Phillips, S. J., Dudík, M. and Schapire, R. E. (2018) Maxent software for modeling species niches and distributions (version 3.4.1). Accessed online $1^{\text {st }}$ September 2018 from http://doi.org/biodiversityinformatics. amnh.org/open_source/maxent/

Piersma, T., Lok, T., Chen, Y., Hassell, C. J., Yang, H. Y., Boyle, A., Slaymaker, M., Chan, Y. C., Melville, D. S., Zhang, Z. W. and Ma, Z. (2016) Simultaneous declines in summer survival of three shorebird species signals a flyway at risk. J. Appl. Ecol. 53: 479-490.

Pyae-Phyo, A., Moses, S., Clark, N., Anderson, G., Hilton, G.M., Buchanan, G.M., Zöckler, C. and Green, R.E. (2018) Recent changes in the number of spoon-billed sandpipers Calidris pygmaea wintering on the Upper Gulf of Mottama in Myanmar. Oryx 54: 23-29.

Rogers, D., Moores, N. and Battley, P. (2006) Northwards migration of shorebirds through Saemangeum, the Geum estuary and Gomso bay, South Korea in 2006. Stilt 50: 62-78.

RSIS (2018) Ramsar Site Information Service Accessed $8^{\text {th }}$ September 2018 from https:// rsis.ramsar.org.

State Council (2018) Circular of the State Council on Strengthening the Protection of Coastal Wetlands and Strictly Controlling the Reclamation. The State Council, People's Republic of China. Accessed online $26^{\text {th }}$ October 2018 from: https://app.www. gov.cn/govdata/gov/201807/25/427280/ article.html?from $=$ singlemessageandisapp installed $=0$ and summarised (in English): http://english.gov.cn/policies/latest_releases/ 2018/07/25/content_281476236284048.htm

Studds, C. E., Kendall, B. E., Murray, N. J., Wilson, H. B., Rogers, D. I., Clemens, R. S., Gosbell, K., Hassell, C. J., Jessop, R., Melville, D. S., Milton, D. A., Minton, C. D. T., Possingham, H. P., Riegen, A. C., Straw, P., Woehler, E. J., and Fuller, R. A. (2017) Rapid population decline in migratory shorebirds relying on Yellow Sea tidal mudflats as stopover sites. Nat. Communic. 8: $1-7$.

Sutherland, W. J., Alves, J. A., Amano, T., Chang, C. H., Nicholas, C., Finlayson, C. M., Gill, J. A., Gill, R. E., González, P. M., Gunnarsson, T. G., Kleijn, D., Spray, C. J. and Székely, T. (2012) A horizon scanning assessment of current and potential future threats to migratory shorebirds. Ibis 154: 663-679.

Swets, J. (1988) Measuring the accuracy of diagnostic systems. Science 240(4857): 1285-1293.

Tomkovich, P. S., Porter, R. R., Loktionov, E. Y. and Niles, L. J. (2013) Pathways and staging areas of Red Knots Calidris canutus rogersi breeding in southern Chukotka, Far Eastern Russia. Wader Study Group Bull. 120: 181193.

Tomkovich, P. S., Syroechkovskiy, E. E., Lappo, E. G. and Zöckler, C. (2002) First indications of a sharp population decline in the globally threatened Spoon-billed Sandpiper Eurynorhynchus pygmeus. Bird Conserv. Internatn. 12: 1-18.

Tong, M., Zhang, L., Jing, L., Zöckler, C. and Clark, N. A. (2012) The critical importance of the Rudong mudflats, Jiangsu Province, China in the annual cycle of the Spoonbilled Sandpiper Calidris pygmeus. Wader Study Group Bull. 119: 74-76.

UNEP-WCMC, IUCN and NGS (2018) Protected Planet Report 2018. Cambridge UK, Gland, Switzerland, and Washington, DC, USA: UNEP-WCMC, IUCN and NGS. Accessed online 16th January 2020 from www.protectedplanet.net 
UNEP-WCMC and IUCN (2018) Protected Planet: The World Database on Protected Areas (WDPA). Cambridge, UK: UNEPWCMC and IUCN. Accessed online 25th September 2018 from www. protectedplanet.net

UNESCO World Heritage Centre (2017) The coast of the Bohai Gulf and the Yellow Sea of China. Accessed online $26^{\text {th }}$ October 2018 from: https://whc.unesco.org/en/ten tativelists/6189/

van der Wal, D., Herman, P. M. J. and Wielemaker-van den Dool, A. (2005) Characterisation of surface roughness and sediment texture of intertidal flats using ERS SAR imagery. Remote Sensing Environ. 98: 96-109.

Vermote, E. (2015) MODIS Terra Surface Reflectance 8-Day L3 Global 5oom SIN Grid Voo6 [Data set]. NASA EOSDIS Land Processes DAAC. Accessed 6th August 2018 from https://doi.org/10.5067/MODIS/ MODogA1.006

Wang, X., Xiao, X., Zou, Z., Chen, B., Ma, J., Dong, J., Doughty, R. B., Zhong, Q., Qin, Y., Dai, S., Li, X., Zhao, B. and Li, B. (2020) Tracking annual changes of coastal tidal flats in China during 1986-2016 through analyses of Landsat images with Google Earth Engine. Remote Sensing Environ. 238: 110987.

Zhang, L., Wang, X., Zhang, J., Ouyang, Z., Chan, S., Crosby, M., Watkins, D., Martinez, J., Su, L., Yu, Y. T., Szabo, J., Cao, L. and Fox, A. D. (2017) Formulating a list of sites of waterbird conservation significance to contribute to China's Ecological Protection Red Line. Bird Conserv. Internatn. 27: 153:166.

Zhang, S., Ma, Z., Choi, C. Y., Peng, H. B., Bai, Q. Q., Liu, W. L., Tan, K., Melville, D. S., He, P., Chan, Y. C., Van Gils, J. A. and Piersma, T. (2018) Persistent use of a shorebird staging site in the Yellow Sea despite severe declines in food resources implies a lack of alternatives. Bird Conserv. Internatn. 28: 534-548.

Zöckler, C., Balachandran, S., Bunting, G. C., Fanck, M., Kashiwagi, M., Lappo, E. G., Maheswaran, G., Sharma, A., Syroechkovski, E. E. and Webb K. (2005) The Indian Sunderbans: an important wintering site for Siberian waders. Wader Study Group Bull. 108: 42-46.

Zöckler, C., Syroechkovskiy, E. E., and Bunting, G. C. (2008) International Single Species Action Plan for the conservation of the Spoon-billed Sandpiper Calidris pygmeus. On behalf of BirdLife International for the CMS.

Zöckler, C., Beresford, A. E., Bunting, G., Chowdhury, S. U., Clark, N. A., Fu, V. W. K., Htin Hla, T., Morozov, V. V., Syroechkovskiy, E. E., Kashiwagi, M., Lappo, E. G., Tong, M., Long, T. L., Yu, Y. T., Huettmann, F., Akasofu, H. K., Tomida, H. and Buchanan, G.M. (2016) The winter distribution of the Spoon-billed Sandpiper Calidris pygmaeus. Bird Conserv. Internatn. 26: 476-489.

Zöckler, C., Syroechkovskiy, E. E., and Atkinson, P. W. (2010a) Rapid and continued population decline in the Spoon-billed Sandpiper Eurynorhynchus pygmeus indicates imminent extinction unless conservation action is taken. Bird Conserv. Internatn. 20: 95-111.

Zöckler, C., Hla, T. H., Clark, N. A., Syroechkovskiy, E. E., Yakushev, N., Daengphayon, S. and Robinson, R. (2010b) Hunting in Myanmar is probably the main cause of the decline of the Spoon-billed Sandpiper Calidris pygmeus. Wader Study Group Bull. 117: 1-8.

Zöckler, C., Li, D., Chowdhury, S., Iqbal, M. and Chenxing, Y. (2018) Winter distribution, habitat and feeding behaviour of Nordmann's Greenshank Tringa guttifer. Wader Study 125: 7-14. 